\title{
EPIDEMIOLOGICAL STUDIES ON JAPANESE ENCEPHALITIS IN KYOTO CITY AREA, JAPAN
}

\section{SEASONAL PREVALENCE OF VIRUS INFECTIONS IN -SEVERAL PIG POPULATIONS SHOWN BY VIRUS RECOVERY FROM ENGORGED CULEX TRITAENIORHYNCHUS SUMMOROSUS}

\author{
Osamu MAEDA, Toshiro KARAKI, Akio KURODA, Osamu SASAKI, \\ YOSHIAKI KAROJI and KUNIHACHI TAKENOKUMA \\ Kyoto City Research Institute of Public Health, Higashi-Takada-cho, \\ Mibu, Nakagyo-ku, Kyoto 604, Japan
}

(Received: April 27, 1977)

\begin{abstract}
SUMMARY : When vector mosquitoes engorged by feeding on pigs are tested for virus recovery after incubation for 7 to 10 days, the results may show mosquito infection itself. Therefore, seasonal prevalence of infection in each pig population can be estimated from course of the infection rate among mosquitoes. Many mosquitoes of the main vector of Japanese encephalitis virus, Culex tritaeniorhynchus summorosus, collected by light traps everyday or every other day in some pig sheds from 1967 to 1970 were tested for virus recovery after incubation. The tests were positive during about a month period each summer, and the peak infection rate was high being over $10 \%$. The course of the mosquito infection showed a certain pattern with one or two peaks between the initial recovery and the highest peak. From the interval of 12 to 13 days after the first recovery to the peak, cyclic infection between the pig and the mosquito may occur at the same interval.
\end{abstract}

\section{INTRODUCTION}

Culex tritaeniorhynchus summorosus is important as the vector of Japanese encephalitis (JE) virus, as the virus is isolated exclusively from this species. The important role of pigs as the amplifying animal has generally been recognized, since Sherer et al. (1959) suggested so on the bases of (a) high incidence of natural infection in pigs, (b) the occurrence of viremia following natural and experimental infection, (c) the infection in C. tritaeniorhynchus by biting viremic pigs, and (d) preference of $C$. tritaeniorhynchus to bite pigs in nature. At some stations around Kyoto City, dissemination of $\mathrm{JE}$ virus in the vector mosquitoes have been investigated annually since 1965 on the basis of virus recovery from unfed $C$. tritaeniorhynchus as reported before (Maeda et al., 1978). The dissemination may have originated mostly from the mosquitoes infected by feeding

前田 理・唐木利明 - 黒田晃生・佐々木 修・唐牛良明・竹之熊国八（京都市衛生研究所 京都市中 京区壬生東高田町 1-2) 
on viremic pigs in pig sheds. Therefore, the study reported in this paper aimed at determining the course of infection in each pig population by a newly deviced method, by which occurrence of viremia in each pig population can be estimated quantitatively.

\section{Materials AND Methods}

Locations for pig sheds: Figure 1 shows the locations for pig sheds, where mosquitoes were collected since 1967. Pig shed $\mathbf{M}$, one of the grouped pig sheds, where about half of 10,000 pigs in Kyoto City area are fed in a limited place along the Kamo River, is located in the southern part of Kyoto City within $200 \mathrm{~m}$ from station "M", the main place for mosquito collection from unfed C. tritaeniorhynchus by use of a dry ice trap every year since 1965. Pig sheds $\mathrm{F}$ and $\mathrm{O}$ are located in the southern part of this city, while pig sheds

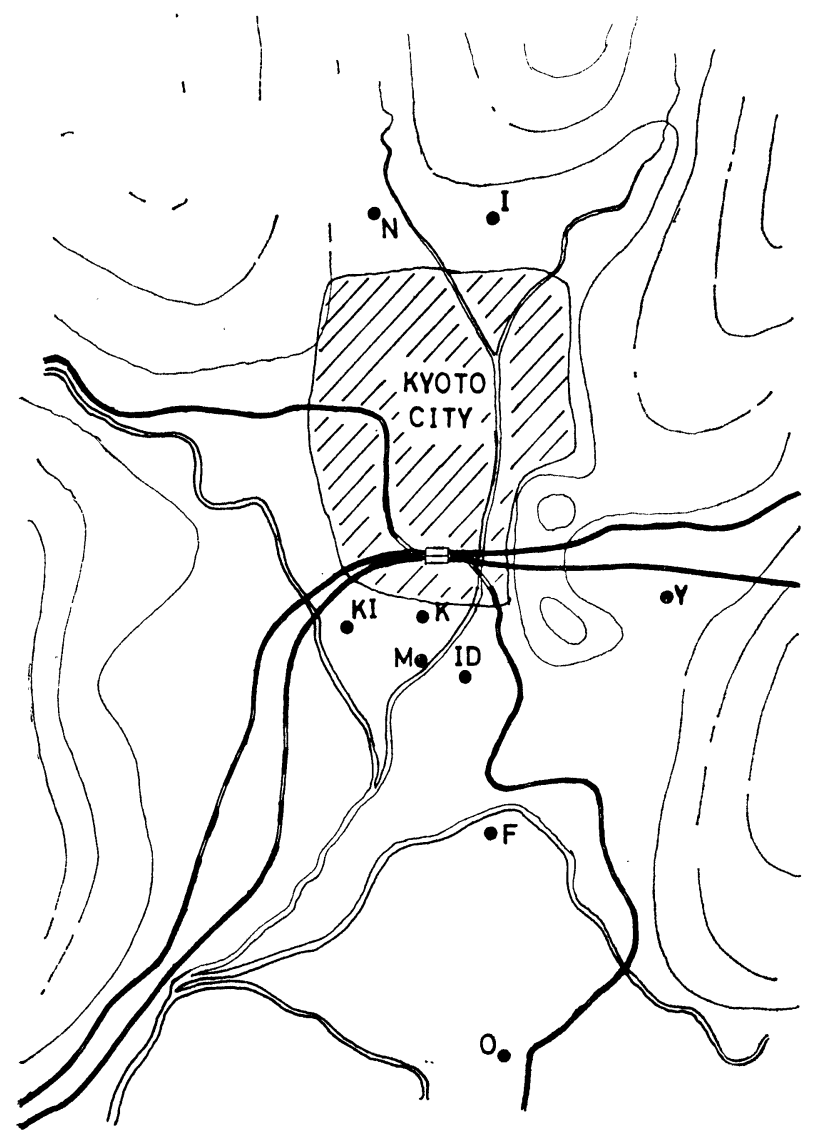

Fig. 1. Locations of pig sheds used for mosquito collection in the Kyoto City area. 
TABLE I

Virus recoveries from fed C. tritaeniorhynchus incubated for 7 to 10 days after collection by the use of light traps in pig sheds

\begin{tabular}{|c|c|c|c|c|c|c|c|}
\hline \multirow{2}{*}{ Year } & \multirow{2}{*}{ Pig shed } & \multicolumn{2}{|c|}{ Period of survey } & \multirow{2}{*}{$\begin{array}{l}\text { Number of } \\
\text { mosquito } \\
\text { collection }\end{array}$} & \multirow{2}{*}{$\begin{array}{l}\text { Number of } \\
C . \text { trit. }\end{array}$} & \multirow{2}{*}{$\begin{array}{l}\text { Total } \\
\text { pools }\end{array}$} & \multirow{2}{*}{$\begin{array}{l}\text { Number of } \\
\text { JE virus } \\
\text { isolated }\end{array}$} \\
\hline & & From & to & & & & \\
\hline \multirow{3}{*}{1967} & Mukoshiro (M) & Jun. 26 & Sep. 8 & 16 & 17000 & 204 & 110 \\
\hline & Fushimi $(\mathbf{F})$ & Jun. 17 & Sep. 8 & 17 & 13660 & 186 & 71 \\
\hline & $\operatorname{Yamashina}(\mathbf{Y})^{1)}$ & Jun. 26 & Aug. 15 & 11 & 13759 & 318 & 126 \\
\hline \multirow{3}{*}{1968} & Iwakura (I) & Jun. 2 & Sep. 10 & 68 & 27488 & 750 & 196 \\
\hline & Mukoshiro (M) & Jul. 1 & Sep. 10 & 25 & 14075 & 508 & 167 \\
\hline & Fushimi (F) & Jun. 15 & Sep. 9 & 54 & 28013 & 707 & 157 \\
\hline \multirow{4}{*}{1969} & Iwakura (I) & Jun. 17 & Aug. 14 & 52 & 28025 & 829 & 233 \\
\hline & Mukoshiro $(\mathbf{M})^{2)}$ & Jun. 18 & Aug. 14 & 52 & 22025 & 476 & 88 \\
\hline & Fushimi (F) & Jun. 26 & Aug. 14 & 45 & 23820 & 688 & 247 \\
\hline & Kamitoba (K) & Jul. 21 & Aug. 15 & 24 & 10370 & 514 & 183 \\
\hline \multirow{3}{*}{1970} & Mukoshiro $(\mathbf{M})^{2)}$ & Jul. 15 & Sep. 12 & 33 & 23811 & 683 & 148 \\
\hline & Okubo $(\mathrm{O})$ & Jul. 15 & Sep. 11 & 28 & 16469 & 497 & 129 \\
\hline & Total & & & 425 & 238515 & 6360 & 1855 \\
\hline
\end{tabular}

1) Breed sows and pigs for fattening were fed in the respective shed.

2) Immunization of pigs with live attenuated $\mathrm{JE}$ vaccine ( $\mathrm{m}$-strain) was performed in the pig shed.

$\mathrm{I}$ and $\mathrm{Y}$ are in the northern and eastern parts, respectively. Pig shed $\mathrm{K}$ is located near M. Pig sheds F, $O$ and I are at short distances of 30 to $300 \mathrm{~m}$ from " $F$ ", "O" and "I", respectively, where unfed C. tritaeniorhynchus were collected.

Mosquito collection: Engorged mosquitoes were collected twice a week in 1967 and everyday or every other day after 1968. Three to six traps of the each Nozawa type with a 6 watt fluorescent lamp were operated at $1.5 \mathrm{~m}$ above pigs in the sleeping place in the shed. Table I gives information on mosquito collection including the names of pig sheds, number of collections and the total number of $C$. tritaeniorhynchus used for virus recovery. To estimate the infection rate of unfed C. tritaeniorhynchus before blood feeding in comparison with that from unfed ones caught in the neighborhood, mosquitoes were also collected by net sweeping at night inside a few pig sheds in the summer of 1968 and 1969. Unfed mosquitoes were used for virus recovery after removing fed ones under a magnifying glass.

Virus recovery from mosquitoes: Engorged mosquitoes caught with the traps were tested for JE virus after incubation for 7 to 10 days in the laboratory with the provision of $1.5 \%$ sucrose solution; unfed ones were tested without incubation. The procedures for virus recovery and estimation of the infection rate have been detailed elsewhere (Maeda et al., 1978).

Method for HI antibody titration: The method for HI antibody titration from blood samples of engorged mosquitoes described by Karaki and Maeda 
TABLE II

Virus recoveries in 1967 from fed C. tritaeniorhynchus incubated for 7 to 10 days after collection

\begin{tabular}{|c|c|c|c|c|c|c|}
\hline $\begin{array}{l}\text { Pig } \\
\text { shed }\end{array}$ & $\begin{array}{l}\text { Virus } \\
\text { isolation }\end{array}$ & Date & $\begin{array}{l}\text { Pool } \\
\text { size }\end{array}$ & $\begin{array}{l}\text { Posi- } \\
\text { tives }\end{array}$ & $\begin{array}{c}\text { Infection } \\
\text { rate } \\
(\%)\end{array}$ & $\begin{array}{c}\text { Duration } \\
\text { of JE virus } \\
\text { positive } \\
\text { (days) }\end{array}$ \\
\hline \multirow{3}{*}{$\mathbf{M}$} & First & Jul. 7 & 200 & $2 / 6$ & 0.20 & \multirow{3}{*}{32} \\
\hline & Peak & $\begin{array}{ll}\text { Jul. } & 18 \\
\text { Jul. } & 20\end{array}$ & $\begin{array}{l}10 \\
10\end{array}$ & $\begin{array}{l}13 / 15 \\
13 / 15\end{array}$ & $\begin{array}{l}18.25 \\
18.25\end{array}$ & \\
\hline & Last & Aug. 7 & 200 & $1 / 6$ & 0.09 & \\
\hline \multirow{3}{*}{ F } & First & Jul. 3 & 200 & $3 / 6$ & 0.28 & \multirow{3}{*}{36} \\
\hline & Peak & Jul. 20 & 25 & $6 / 6$ & 15.00 & \\
\hline & Last & Aug. 7 & 100 & $1 / 6$ & 0.18 & \\
\hline \multirow{3}{*}{$\mathbf{Y}$} & First & Jul. 3 & 200 & $3 / 8$ & 0.23 & \multirow{3}{*}{25} \\
\hline & Peak & Jul. 17 & 1 & $23 / 69$ & 33.33 & \\
\hline & Last & Jul. 27 & 50 & $6 / 8$ & 2.73 & \\
\hline
\end{tabular}

(1966) was supplementarily used for estimating rise of $\mathrm{HI}$ antibody in each pig population. Pools of 100 engorged mosquitoes comprising mainly C. tritaeniorhynchus collected with the same light traps as used for virus recovery were ground in $2 \mathrm{ml}$ of phosphate buffered saline ( $\mathrm{pH} \mathrm{7.2)} \mathrm{and} \mathrm{centrifuged} \mathrm{at}$ $3,000 \mathrm{rpm}$ for $15 \mathrm{~min}$. The supernatant was employed for the test.

Immunization with vaccine: In 1969, vaccination of pigs was performed at the grouped pig sheds including M. A total of 4,763 pigs over three months' old having no experience of summer was vaccinated once with $2 \mathrm{ml}$ of the live attenuated $\mathrm{JE}$ vaccine (m-strain) produced by Inoue (1964) during the periods from June 12 to 17 or from July 14 to 17 . In 1970 , the vaccination programs were extended to all pig sheds all over the Kyoto City area. About 8,900 pigs were vaccinated once with the m-strain during the period from June 1 to 24 .

\section{Results}

Table I shows JE virus recovery from engorged C. tritaeniorhynchus after incubation for about a week. A total of 6,360 pools of 238,515 G. tritaeniorhynchus, caught in the pig sheds during the four years, was examined. JE virus isolation totalled 1,855 . The yearly results including the infection rates at the beginning, the peak and the termination of surveillance at each pig shed from 1967 to 1970 are presented in Tables II to V. JE virus infection rates and the rise of $\mathrm{HI}$ antibody in each pig population are illustrated in Figs. 2 to 5 for each year in comparison with the period of virus recovery from unfed ones caught by dry ice collection.

Results in 1967: JE virus was recovered from engorged C. tritaeniorhynchus in every pig shed in early July, prior to the recovery from unfed ones at station 


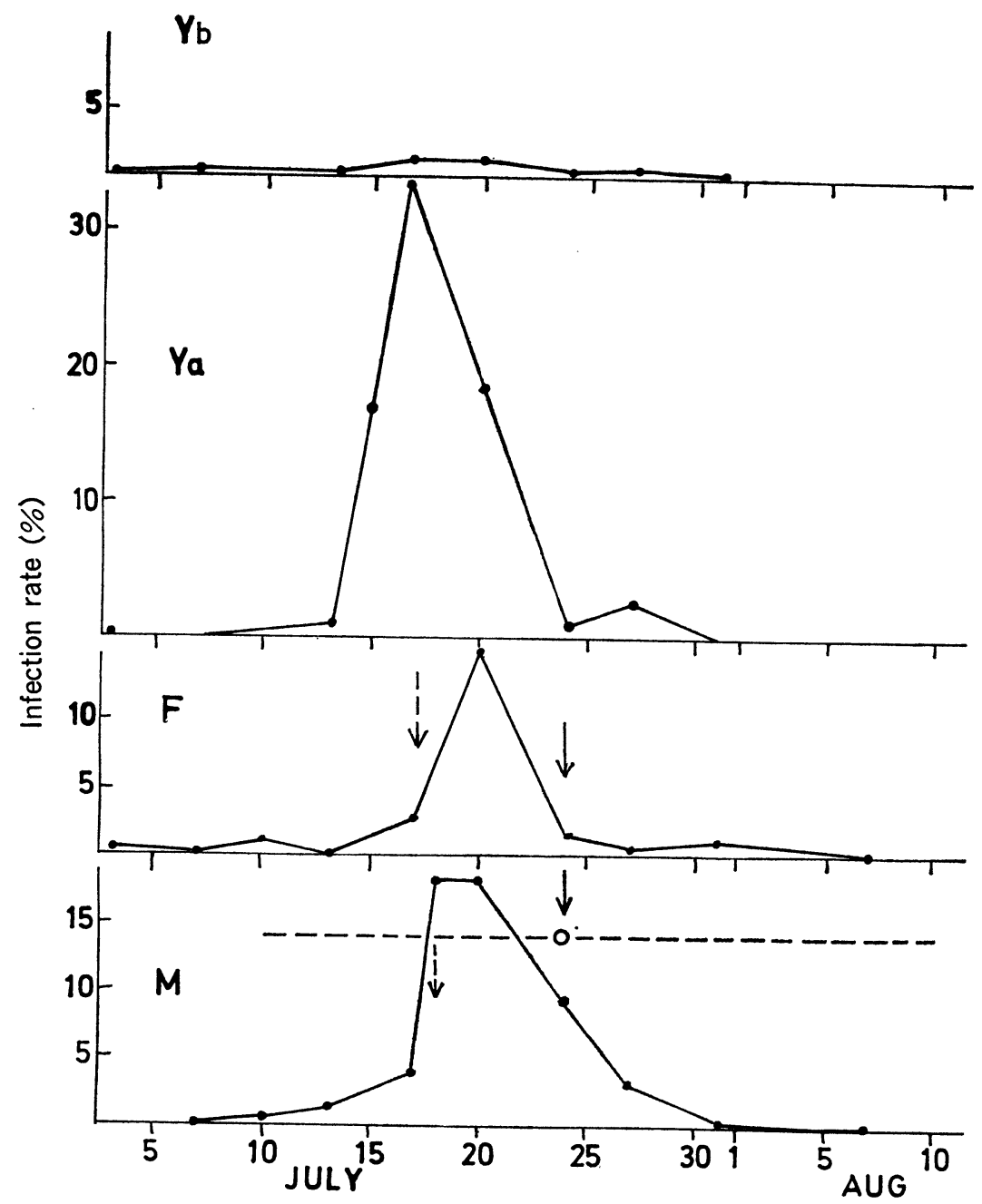

Fig. 2. Course of JE virus infection in each pig population in 1967 shown by a rise in HI antibody ( $\downarrow 40$ and $\downarrow 640$ ) and virus recoveries $(-\odot \rightarrow)$ from engorged C. tritaeniorhynchus incubated for 7 to 10 days after collection at each pig shed, in comparison with the duration (-..) and the peak $(O)$ of the recoveries from unfed ones.

" $M$ " by dry ice collection (Table II and Fig. 2). In the period of one to two weeks after the first recovery at each shed, the infection rates were below $5 \%$. However, abrupt increase in the rate occurred in the middle of July. A particularly high rate at the peak was found on July 17 in one shed (Ya), where only pigs for fattening were feeding. Such high rates were obtained from 23 positives out of 69 mosquitoes. The rate was the highest throughout the survey for four years. However, the rates with mosquitoes engorged on sows for breeding or piglets in another shed $(\mathrm{Yb})$, separated from Ya with walls, were below 


\section{TABLE III}

Virus recoveries in 1968 from fed C. tritaeniorhynchus incubated 7 to 10 days after collection

\begin{tabular}{|c|c|c|c|c|c|c|}
\hline $\begin{array}{l}\text { Pig } \\
\text { shed }\end{array}$ & $\begin{array}{l}\text { Virus } \\
\text { isolation }\end{array}$ & Date & $\begin{array}{l}\text { Pool } \\
\text { size }\end{array}$ & $\begin{array}{l}\text { Posi- } \\
\text { tives }\end{array}$ & $\begin{array}{l}\text { Infection } \\
\text { rate } \\
(\%)\end{array}$ & $\begin{array}{c}\text { Duration } \\
\text { of JE vivus } \\
\text { positive } \\
\text { (days) }\end{array}$ \\
\hline \multirow{3}{*}{ I } & First & Jul. 10 & 50 & $1 / 10$ & 0.21 & \multirow{3}{*}{41} \\
\hline & Peak & Aug. 4 & 10 & $16 / 24$ & 10.40 & \\
\hline & Last & Aug. 19 & 50 & $3 / 19$ & 0.34 & \\
\hline \multirow{3}{*}{$\mathbf{M}$} & First & Jul. 15 & 50 & $11 / 24$ & 1.22 & \multirow{3}{*}{36} \\
\hline & Peak & Aug. 3 & 10 & $12 / 24$ & 6.70 & \\
\hline & Last & Aug. 19 & 25 & $2 / 24$ & 0.35 & \\
\hline \multirow{3}{*}{$\mathbf{F}$} & First & Jul. 15 & 50 & $2 / 24$ & 0.17 & \multirow{3}{*}{29} \\
\hline & Peak & Aug. 2 & 10 & $19 / 24$ & 14.51 & \\
\hline & Last & Aug. 12 & 25 & $2 / 14$ & 0.61 & \\
\hline
\end{tabular}
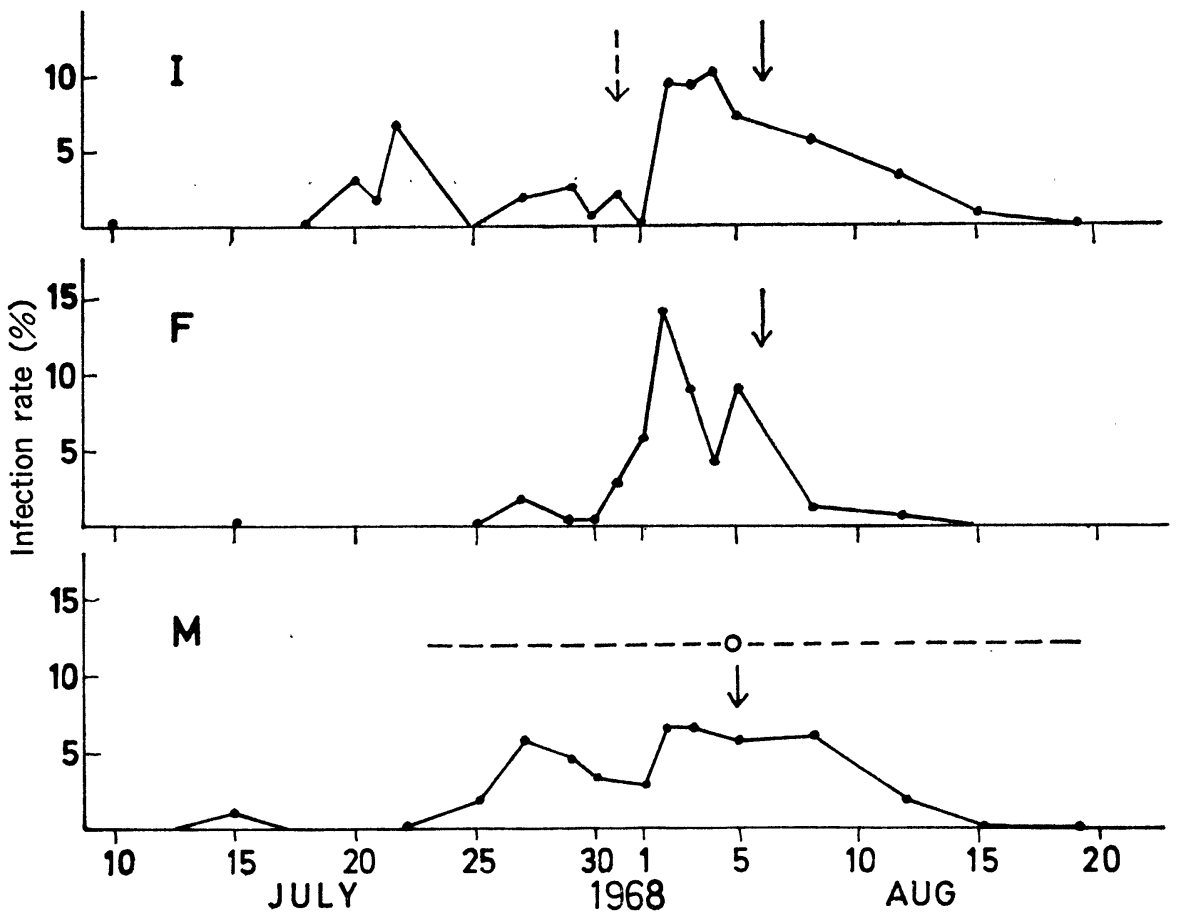

Fig. 3. Course of JE virus infection in each pig population in 1968. Symbols are the same as those in Fig. 2. 
$2 \%$ during July. The peaks of virus recovery from engorged mosquitoes at $\mathbf{F}$ and $\mathbf{M}$ occurred later and the infection rates were slightly lower than that at $\mathrm{Ya}$. The rise of $\mathrm{HI}$ antibody at $\mathbf{F}$ and $\mathbf{M}$ occurred at a low titer just before the peak and at a higher titer afterwards. The virus was recovered from unfed mosquitoes caught at station " $M$ " with a slight delay in comparison with the recovery from engorged ones in similar duration.

Results in 1968: Mosquitoes were collected almost everyday or every other day in the pig sheds in 1968, but twice a week before July 25 at $\mathrm{M}$ and after August 5 at every shed. Detailed information is shown in Table III and Fig. 3. The virus was first recovered at such a low rate as $0.21 \%$ from the mosquitoes caught on July 10 at $I$ in the northern part of Kyoto City. While, at two other sheds, $M$ and $F$, in the southern part, the virus was first recovered on the same day, July 15, although the infection rates were different, 0.17 and $1.22 \%$, respectively. Subsequently, no virus was recovered from the mosquitoes caught in any shed during the period of 7 to 9 days after the first recovery. At $I$, the second recovery after July 18 continued for 5 days with the second peak of $6.7 \%$ on July 22. After a one-day disappearance on July 24, the virus was recovered continuously with a peak of $10.4 \%$ on August 4 . At F, the virus was recovered from mosquitoes continuously during in the period from July 25 to August 12 with the highest peak of $14.5 \%$ on August 2. At M, it was also recovered continuously from July 22 till August 19; the infection rates were high over $5 \%$, but exceptionally low on August 1, although the peak was indistinct. The recovery was the same to or slightly sooner than that from unfed mosquitoes at

TABLE IV

Virus recoveries in 1969 from fed C. tritaeniorhynchus incubated for 7 to 10 days after collection

\begin{tabular}{|c|c|c|c|c|c|c|}
\hline $\begin{array}{l}\text { Pig } \\
\text { shed }\end{array}$ & $\begin{array}{l}\text { Virus } \\
\text { isolation }\end{array}$ & Date & $\begin{array}{l}\text { Pool } \\
\text { size }\end{array}$ & $\begin{array}{l}\text { Posi- } \\
\text { tives }\end{array}$ & $\begin{array}{c}\text { Infection } \\
\text { rate } \\
(\%)\end{array}$ & $\begin{array}{l}\text { Duratson } \\
\text { of JE virus } \\
\text { positive } \\
\text { (days) }\end{array}$ \\
\hline \multirow{3}{*}{ I } & First & Jul. 15 & 50 & $1 / 12$ & 0.17 & \multirow{3}{*}{31} \\
\hline & Peak & Jul. 28 & 5 & $13 / 24$ & 14.45 & \\
\hline & Last & Aug. 14 & 50 & $4 / 12$ & 0.81 & \\
\hline \multirow{3}{*}{$\mathbf{M}$} & First & Jul. 7 & 50 & $1 / 15$ & 0.14 & \multirow{3}{*}{36} \\
\hline & Peak & Aug. 2 & $\begin{array}{l}50 \\
10\end{array}$ & $\begin{array}{r}10 / 12 \\
3 / 12\end{array}$ & 3.18 & \\
\hline & Last & Aug. 11 & 50 & $7 / 24$ & 0.69 & \\
\hline \multirow{3}{*}{$\mathbf{F}$} & First & Jul. 6 & 50 & $1 / 12$ & 0.17 & \multirow{3}{*}{37} \\
\hline & Peak & Aug. 3 & 10 & $15 / 24$ & 9.35 & \\
\hline & Last & Aug. 11 & 50 & $1 / 6$ & 0.36 & \\
\hline \multirow{3}{*}{ K } & First & Jul. 24 & 50 & $2 / 12$ & 0.36 & \multirow{3}{*}{21} \\
\hline & Peak & $\begin{array}{ll}\text { Aug. } & 6 \\
\text { Aug. } & 7\end{array}$ & $\begin{array}{l}10 \\
10\end{array}$ & $\begin{array}{l}18 / 24 \\
18 / 24\end{array}$ & $\begin{array}{l}12.94 \\
12.94\end{array}$ & \\
\hline & Last & Aug. 13 & 25 & $5 / 10$ & 2.73 & \\
\hline
\end{tabular}




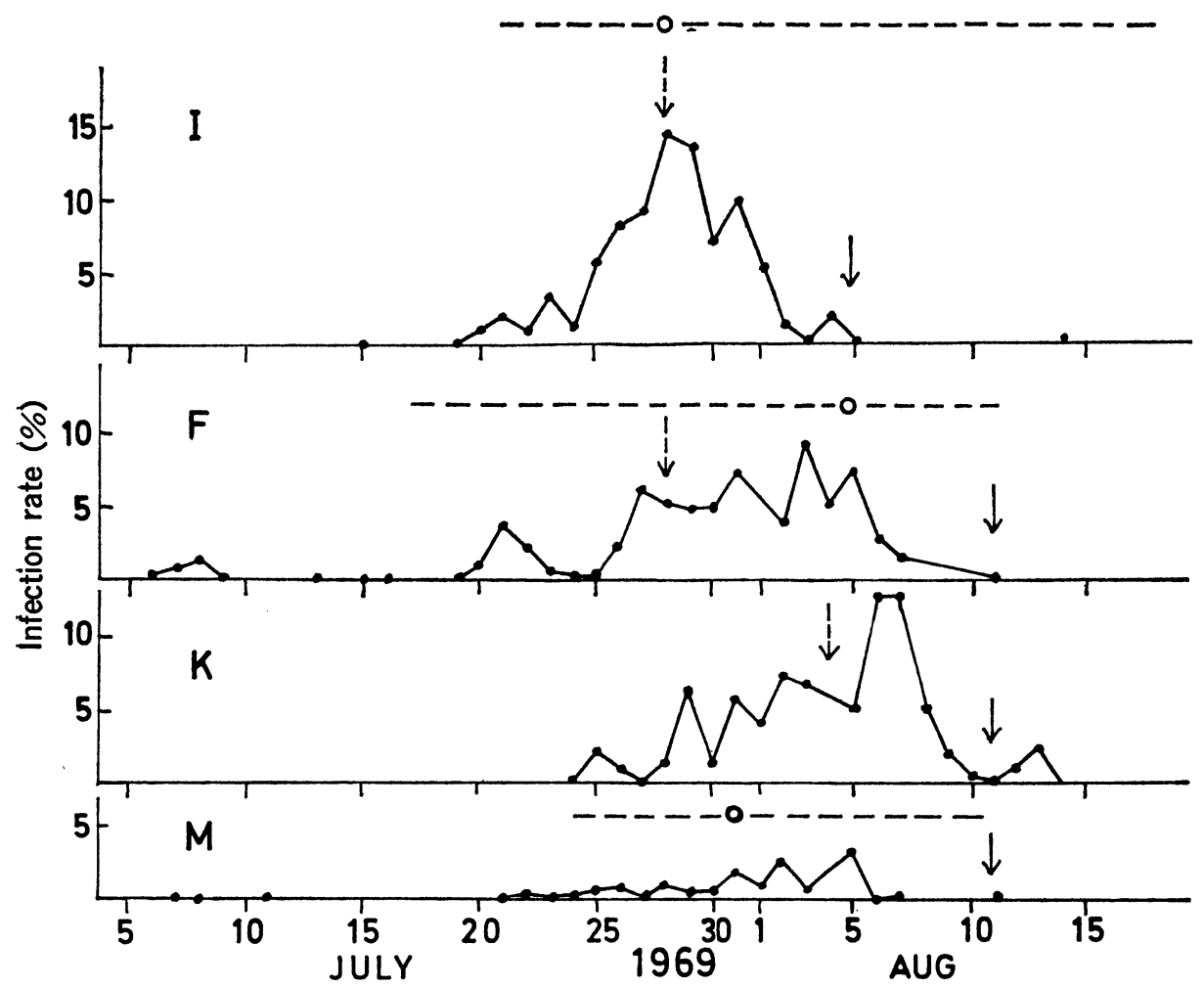

Fig. 4. Course of JE virus infection in each pig population in 1969. Symbols are the same as those in Fig. 2.

station "M". A high rise of $\mathrm{HI}$ antibody in each pig population occurred with a few days' delay from the peak of virus recovery from engorged mosquitoes.

Results in 1969: Mosquitoes were collected in sheds I, F and M as were in the preceding year and additionally in shed $\mathrm{K}$. Detailed information is shown in Table IV and Fig. 4. At F, the virus was recovered first during four days after July 6 at a maximum rate of $1.61 \%$ and afterwards discontinuously at lower rates below $3.8 \%$. The second rise in the rate occurred from July 19 with a peak of $4.0 \%$ on July 20 . At I, no virus was recovered before July 15 , although about 13,500 C. tritaeniorhynchus were tested during the period from June 17 to July 14; the recovery continued from July 19 to the peak of $14.45 \%$ on July 28. At $M$, the virus was first recovered from July 7 to 11 . After no recovery for 9 days, it was recovered continuously from July 21 to August 11 at low rates below $3.5 \%$. At $\mathrm{K}$ near $\mathrm{M}$, the virus was recovered first on July 24; no mosquito was collected for the test before July 20. The infection rates gradually increased with daily variation and attained the maximum of $12.94 \%$ on August 6 and 7. The virus was recovered from unfed C. tritaeniorhynchus caught at each station during the period from the second rise to the termination 
of recovery from engorged ones. HI antibody at low titer was detected in each pig population in the midst of recovery. It was detected in the first samples from $M$ for immunization, and attained high titers at the end of recovery.

Results in 1970: The immunization program for pigs was extended all over the Kyoto City sera. Pig shed $O$ in the suburban area of Uji City, adjacent to Kyoto City, was chosen as an untreated control for evaluating the immunization in comparison with the results at $M$. Detailed information is presented in Table $\mathrm{V}$ and Fig. 5. At $\mathrm{M}$, the virus was recovered continuously from engorged mosquitoes for 42 days from August 2 to September 12 at relatively high rates of over $3 \%$ during the period from August 15 to 25. At $\mathrm{O}$, however, the virus was recovered first on the same day, August 2, and the pattern of recovery with two

\section{TABLE V}

Virus recoveries in 1970 from fed C. tritaeniorhynchus incubated for 7 to 10 days after collection

\begin{tabular}{cllcccc}
\hline $\begin{array}{l}\text { Pig } \\
\text { shed }\end{array}$ & $\begin{array}{c}\text { Virus } \\
\text { isolation }\end{array}$ & Date & $\begin{array}{l}\text { Pool } \\
\text { size }\end{array}$ & $\begin{array}{c}\text { Posi- } \\
\text { tives }\end{array}$ & $\begin{array}{c}\text { Infection } \\
\text { rate } \\
(\%)\end{array}$ & $\begin{array}{c}\text { Duration } \\
\text { of JE virus } \\
\text { positive } \\
\text { (days) }\end{array}$ \\
\hline \multirow{3}{*}{ M } & First & Aug. 2 & 50 & $1 / 24$ & 0.09 & \\
& Peak & Aug. 15 & 10 & $15 / 24$ & 9.35 & 42 \\
& Last & Sep. 12 & 10 & $1 / 12$ & 0.87 & \\
\hline \multirow{3}{*}{ O } & First & Aug. 2 & 50 & $5 / 22$ & 0.51 & 31 \\
& Peak & Aug. 11 & 10 & $18 / 24$ & 12.94 & 31 \\
& Last & Sep. 1 1 & 25 & $1 / 7$ & 0.61 & \\
\hline
\end{tabular}

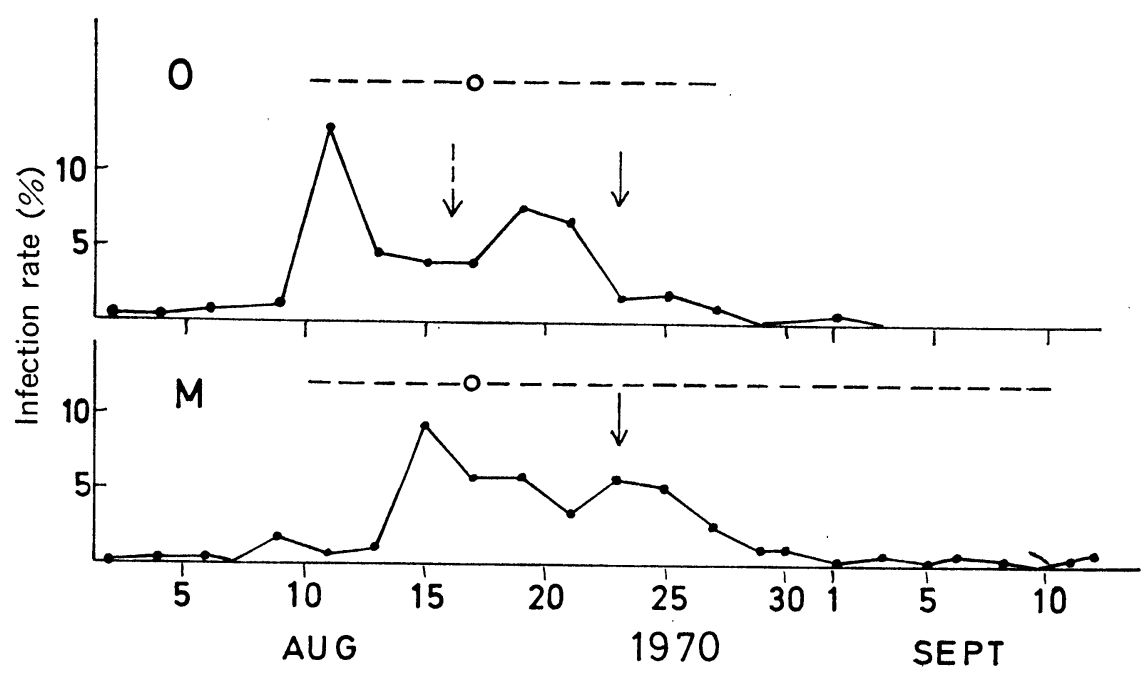

Fig. 5. Course of JE virus infection in each pig population in 1970. Symbols are same as those in Fig. 2. 
peaks is similar to that at M. The virus recovery from mosquitoes terminated after a duration shorter than that at $\mathrm{M}$, and the infection rate over $3 \%$ continued from the abrupt rise on August 11. The recovery from unfed mosquitoes began with a delay of about a week from that from engorged ones at both stations and continued for the same period. HI antibody in the first sample of engorged mosquitoes from pig population at $M$ was detected at high titers in the samples from each pig population at the end of virus recovery.

Virus recovery from mosquitoes caught by net sweeping: Virus recovery from unfed $C$. tritaeniorhynchus caught by net sweeping is shown in Table VI in comparison with that from unfed ones collected by use of a dry ice trap in the neighborhood. No significant difference was seen in the infection rate between samples caught by the two methods at the same time.

\section{TABLE VI}

Comparison of the infection rate between unfed $\mathrm{C}$. tritaeniorhynchus caught by net sweeping in pig sheds and those caught by the dry ice trap in the neighborhood

\begin{tabular}{|c|c|c|c|c|c|c|c|c|c|c|}
\hline Year & $\begin{array}{l}\text { Pig } \\
\text { shed }\end{array}$ & Date & $\begin{array}{l}\text { Pool } \\
\text { size }\end{array}$ & $\begin{array}{l}\text { Posi- } \\
\text { tives }\end{array}$ & $\begin{array}{c}\text { Infec- } \\
\text { tion } \\
\text { rate } \\
(\%)\end{array}$ & $\begin{array}{l}\text { Sta- } \\
\text { tion }\end{array}$ & Date & $\begin{array}{l}\text { Pool } \\
\text { size }\end{array}$ & $\begin{array}{l}\text { Posi- } \\
\text { tives }\end{array}$ & $\begin{array}{c}\text { Infec- } \\
\text { tion } \\
\text { rate } \\
(\%)\end{array}$ \\
\hline \multirow{4}{*}{1968} & $\mathbf{M}$ & Aug. 1 & 100 & $11 / 19$ & 0.86 & $\mathbf{M}$ & Aug. 1 & 100 & $1 / 7$ & 0.52 \\
\hline & & & & & & $\mathbf{M}$ & Aug. 5 & 100 & $9 / 12$ & 1.37 \\
\hline & $\mathbf{M}$ & Aug. 8 & 100 & $8 / 22$ & 0.90 & $\mathbf{M}$ & Aug. 8 & 100 & $12 / 24$ & 0.69 \\
\hline & M & Aug. 12 & 50 & $1 / 11$ & 0.90 & $\mathbf{M}$ & Aug. 12 & $\begin{array}{r}100 \\
50\end{array}$ & $\begin{array}{r}8 / 12 \\
3 / 12\end{array}$ & 0.84 \\
\hline \multirow{2}{*}{1969} & $\mathbf{M}$ & Aug. 7 & 100 & $1 / 20$ & 0.05 & $\bar{M}$ & Aug. 7 & 100 & $5 / 24$ & 0.23 \\
\hline & $\mathbf{F}$ & Aug. 11 & 50 & $0 / 7$ & 0 & $\mathbf{F}$ & Aug. 11 & 50 & $2 / 7$ & 0.34 \\
\hline
\end{tabular}

\section{TABLE VII}

Recoveries of JE virus from fed mosquitoes of other than Culex tritaeniorhynchus

\begin{tabular}{|c|c|c|c|c|c|c|c|c|}
\hline \multirow{2}{*}{ Species } & \multirow{2}{*}{ Year } & \multirow{2}{*}{$\begin{array}{l}\text { Pig } \\
\text { shed }\end{array}$} & \multicolumn{2}{|c|}{$\begin{array}{l}\text { Period of } \\
\text { survey }\end{array}$} & \multirow{2}{*}{$\begin{array}{l}\text { Number of } \\
\text { mosquitoes } \\
\text { tested }\end{array}$} & \multirow{2}{*}{$\begin{array}{c}\text { Number of } \\
\text { pools } \\
\text { tested }\end{array}$} & \multirow{2}{*}{$\begin{array}{l}\text { Number of } \\
\text { JE virus } \\
\text { isolated }\end{array}$} & \multirow{2}{*}{$\begin{array}{l}\text { Date of } \\
\text { collection } \\
\text { of positive } \\
\text { mosquito }\end{array}$} \\
\hline & & & From & to & & & & \\
\hline \multirow{6}{*}{ 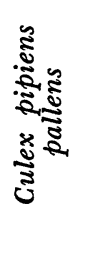 } & 1967 & M & Jun. 26 & Jul. 31 & 915 & 12 & 0 & \multirow{6}{*}{$\begin{array}{l}\text { Aug. } 4 \\
\text { Aug. } 6\end{array}$} \\
\hline & 1967 & ID & Jun. 26 & Jul. 7 & 384 & 2 & 0 & \\
\hline & 1968 & $\mathbf{M}$ & Jun. 1 & Jul. 11 & 275 & 4 & 0 & \\
\hline & 1968 & F & Jun. 9 & Jul. 11 & 2364 & 37 & 2 & \\
\hline & 1968 & I & Jun. 2 & Aug. 14 & 1586 & 26 & 0 & \\
\hline & & Total & & & 5524 & 81 & 2 & \\
\hline \multirow{5}{*}{ 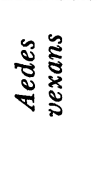 } & 1967 & M & Jun. 6 & Jun. 26 & 353 & 3 & 0 & \\
\hline & 1968 & M & Jul. 1 & Jul. 11 & 275 & 4 & 0 & \\
\hline & 1968 & $\mathbf{F}$ & Jun. 9 & Aug. 10 & 1370 & 27 & 0 & \\
\hline & 1968 & I & Jun. 2 & Aug. 12 & 1707 & 24 & 0 & \\
\hline & & Total & & & 3705 & 58 & 0 & \\
\hline
\end{tabular}


Virus recovery from engorged mosquitoes of other species than $\mathrm{C}$. tritaeniorhynchus: Table VII shows virus recovery from engorged mosquitoes of other species than C. tritaeniorhynchus in 1967 and 1968. JE virus was recovered from two samples of Culex pipiens pallens collected on August 4 and 6, 1968, at pig shed F. However, no virus was recovered from Aedes vexans engorged in any pig shed.

\section{Discussion}

JE virus recovery from and $\mathrm{HI}$ antibody titers of samples of engorged $C$. tritaeniorhynchus caught with light traps in each pig shed may represent the occurrence of viremia and $\mathrm{HI}$ antibody, respectively, in the pig population. Pigs probably develop $\mathrm{HI}$ antibody after a period of viremia causing mosquito infection usually for not longer than two days as described by Hurlbut (1964). Virus recovery at a low infection rate began usually prior to a slight rise of HI antibody, a high rise of the antibody occurred usually after the peak of mosquito infection. However, the virus recovered from engorged mosquitoes may have probably originated from the infection either at the time or before feeding on viremic pigs. To answer this question, infection rates were compared between unfed mosquitoes caught by net sweeping in each pig shed and unfed ones caught by use of the dry ice trap in the neighborhood. The results show no significant difference between them. The rate with unfed mosquitoes was generally much lower than that with engorged ones. Therefore, a greater part of infection of engorged ones may have been due to feedings on viremic pigs. Then infection of mosquitoes engorged on each pig population was investigated in detail in comparison with those of unfed ones.

It is generally said that $C$. tritaeniorhynchus is the major vector of JE virus in Japan as the virus is frequently recovered from this species. It is also regarded that pigs are the most important amplifier of this virus because of high incidence of natural pig infection, the preference of $C$. tritaeniorhynchus for pigs (Sherer et al., 1959), the high correlation between human morbidity from JE and pig density (Ueba et al., 1968), and the proven pig-mosquito cycle of JE virus (Konno et al., 1965). These opinions have been confirmed by the present findings. High infection rates of $\mathrm{JE}$ virus of over $10 \%$ were obtained after incubation for 7 to 10 days of $C$. tritaeniorhynchus engorged on each pig population. C. pipiens pallens may probably be less susceptible than was $C$. tritaeniorhynchus as the virus was isolated from only two pools out of $5,140 \mathrm{C}$. pipiens pallens. It is interesting that no virus was recovered, even after incubation, from Aedes vexans having fed on the same pig population as had $C$. tritaeniorhynchus. Isolation of the virus from this species was reported by Shichijo et al. (1970). The discrepancy may suggest that the natural infection in Nagasaki Prefecture may be questionable or that the virus may have developed so slowly in the body of Aedes vexans that it was undetectable in 7-10 days of incubation.

As mentioned above, the infection rate of unfed $C$. tritaeniorhynchus caught 
by the dry ice trap at each station was, at the most, about $3 \%$, but may be much lower at the time of first recovery from engorged ones in each pig shed every year. For example, the infection rate calculated from one positive out of 24 pools of 100 unfed mosquitoes caught on July 23, 1968, at station " $M$ " is $0.04 \%$, while that from 11 positives out of 24 pools of 50 engorged ones caught on July 15 at nearby pig shed $M$ is $1.22 \%$. For another example, the infection rate calculated from one positive out of 21 pools of 100 unfed mosquitoes caught on July 21,1969 , at station " $I$ " is $0.04 \%$, while that from 5 positives out of 12 pools of 25 engorged ones caught in nearby pig shed I on the same day is. $2.13 \%$. Thus the infection rate of engorged mosquitoes at the time of first recovery every year are much higher than that of unfed ones, and may probably indicate the occurrence of viremia in pigs even if the infection rate is low.

On such an assumption, the pattern of virus infection among each pig population can be estimated from the time-course of the infection rate from engorged mosquitoes, more strictly, by substructing the rate of unfed ones. from it. This procedure can be applied for evaluation of immunization of pigs. In the data at $\mathrm{M}$ in 1969, the depression of viremia can be assumed from the low infection rates during the period of about a month. In 1970, however, the depression was probably not so effective because the rates were high over $5 \%$ in the period from August 15 to 25. Tsuchiya et al. (1965) explained that half of the immune pigs were replaced with untreated younger ones before the middle of August two months after the vaccination because dissemination of $\mathrm{JE}$ virus in this district in that year was unexpectedly delayed.

The data of virus recovery from engorged mosquitoes in 1968 and 1969 are useful for detailed investigation on the patterns of virus infection in each pig population. The prevalence of JE virus shown by the recovery from unfed mosquitoes seems to occur at the same time at different stations each year, as the period of virus recovery varied from year to year but not among stations in each year as described before (Maeda et al., 1978). However, from the data on virus recovery from engorged mosquitoes, infection of pigs may not occur at the same time in all pig sheds. For example, recovery at northern pig shed I began initially on July 10, 1968, and continued to the second detection which began from July 20, while at southern $F$ and $M$, the recovery began on July 15 and continued to the second detection from July 25. From this result, the time of acquisition of JE virus by these pig populations seem to be different. Besides, it is very important that the peak of the second detection occurred on the 12th to 13th day after the first recovery as seen at I, F and M, in 1968 and at F, in 1969, and continued to the third rise in the infection rate after the same period with intermediary peaks typically seen in the result at $I$, in 1968, and at F, in 1969. These results may indicate that mosquitoes, infected by feeding on viremic pigs at the time of the first detection, became infective in 10 to 11 days after infection, as described by Takahashi (1967). They transmitted the virus to other susceptible pigs, in which maximum viremia occurred on the second day after the infection as assumed from the data of Hurlbut (1969). This may lead. 
to another assumption that mosquitoes bite at intervals of 5 to 6 days and transmit the virus to other susceptible pigs in the second feeding or later. Discontinuous detection between the first recovery and the second peak, as seen at $\mathrm{F}$ in 1969, may show that infected mosquitoes come for feeding after the infection. The intermediary detection between the second and third peaks as seen at I, in 1968, may probably show that viremic pigs were infected by the third feeding by infective mosquitoes. The rates of infection at $I$ and $K$ in 1969 are different from those in other sheds: no virus was recovered 12 to 13 days before the rise in the infection rate. If we assume that the first rise in the infection rate corresponds with the second peak at other sheds, it may well be explained that the rates of infection at $\mathrm{I}$ and $\mathrm{K}$ in 1969 resemble that at $\mathrm{F}$ in 1968. No mosquito was collected for virus recovery before the second peak at $\mathrm{K}$ in 1969. At $\mathrm{I}$, in 1969, no virus was recovered from 42 pools of 2,575 mosquitoes collected during the period from July 7 to 10 , when the first infection of pigs occurred in this pig shed. Therefore, the second rise in the infection rate may show pig infection by feeding by infective mosquitoes produced in an other pig population.

Thus, incidence of virus infection in each pig population can be estimated from the course of the infection rate among engorged mosquitoes, showing one or two peaks of the rate. Such patterns may implicate many factors, while will be analyzed to explain in detail JE epidemics in a separate paper.

\section{AcKNOWLEDGEMENTS}

We would like to express appreciation in our grateful remembrane of late Dr. Natsumi Tsuchiya who contributed to the accomplishment of this research with his leadership and encouragement during the period from 1967 to 1973 . We gratefully acknowledge many helpful discussions given by Dr. Akira Oya, National Institute of Health, Prof. Yoshikatsu Ozaki, Shiga University of Medical Science, and members of the Society for Ecological Research of Japanese Encephalitis Virus in Japan. We are also indebted to our laboratory assistants for their laborious help in this research and to the owners of each pig farm for their cooperation in this investigation.

\section{REFERENCES}

Hurlbut, H. S. (1964): The pig mosquito cycle of Japanese encephalitis in Taiwan. J. Med. Entomol., 1, 301-307.

Inoue, Y. K. (1964): An attenuated mutant of Japanese encephalitis virus. Bull. WHO, 30, 181-185.

KaRAKr, T. AND MAEDA, O. (1968): Use of engorged mosquitoes for titration of HI antibody to Japanese encephalitis virus in pigs. Igaku-no-Ayumi, 65, 582-586 (in Japanese).

Konno, J., Endo, K., Agatsuma, H. And Ishida, N. (1965): Cyclic outbreak of Japanese encephalitis among pigs and humans. Am. J. Epidemiol., 84, 292-300.

Maeda, O., Karaki, T., Kuroda, A., Karoji, Y., Sasaki, O. and Takenokuma, K. (1978): Epidemiological studies on Japanese encephalitis in Kyoto City area, Japan. II. Annual patterns of virus dissemination on virus recoveries from unfed Culex tritaeniorhynchus summorosus. Japan. J. Med. Sci. Biol., 31, 39-51.

Sherer, W. F., Moyer, J. T., Izumi, T., Gresser, I. And McCown, J. (1959): Ecologic studies of Japanese encephalitis virus in Japan. VI. Swine infection. Am. J. Trop. Med. Hyg., 12, 698-706. 
Shichijo, A., Mifune, K., Chin, C. C., Hayashi, K., Wada, Y., Ito, S., Oda, T., Omori, N., SUENAGA, O. AND MIYAGI, I. (1970): Isolation of Japanese encephalitis virus and group A arbovirus from Aedes vexans nipponi in Nagasaki area, Japan. Trop. Med., 12, 91-97 (in Japanese).

TAKAFASHI, M. (1967): Ecology and physiology of vector mosquito of Japanese encephalitis virus. Adv. Neurol. Sci., 11, 11-18 (in Japanese).

Tsuchiya, N., Karaki, T., KURoda, A., Karoji, Y. and Sasaki, O. (1970): Field studies on immunization of swines using live attenuated Japanese encephalitic vaccine. Virus, 20, 26-36 (in Japanese).

Ueba, N., Maeda, A., Buei, K., Mitsuta, B., Ohtu, T., Kimoto, T., Munita, N. and Arai, H. (1968): Ecological studies on Japanese encephalitis virus in Osaka Prefecture (1963-1967). Japan. J. Publ. Hlth, 18, 267-275 (in Japanese). 